\title{
A GENRE-BASED TRANSLATION OF WATCH PROMOTIONAL TEXT IN COLOURS MAGAZINE OF GARUDA INDONESIA AIRLINE
}

\author{
Tefur Nur Rohman \\ Tefurrohman5@gmail.com \\ Universitas Jenderal Soedirman \\ Jl. Profesor DR. HR Boenyamin No.708, Purwokerto, Indonesia 53122
}

\begin{abstract}
This study aims to identify and describe the genre text, types of theme, mood, transitivity in systemic functional linguistics, and translation techniques This research is a descriptive, qualitative research. The data sources in this study are watch advertisements in Colours Magazine January Edition, the year 2016 until 2018. The data studied in this study were genre text, translation techniques, theme, mood and transitivity in systemic functional linguistics which were obtained from Colours Magazine in part watch promotional text. The sampling technique used is purposive sampling. The result showed that the translation is getting better year by year based on the appearance and systemic functional linguistics. There are no much changes between the target language and source language.
\end{abstract}

Keywords: Genre text, Systemic functional linguistics, Watch promotional text, Colours magazine, Garuda Indonesia.

\section{Introduction}

Globalization era forcing people in the world to be more creative and aware facing every single phenomenon that happens around. As the person who lives in globalization, we should develop our knowledge. Moreover, the knowledge comes from every spot in this world. To get the knowledge from another country, we should know their language. So, if we are mastering languages in the world, our knowledge would be increasing faster than others who only masters in one language. Most of people just mastering in one language, so it is the mistake. However, smart people use that situation to get money. Some people are mastering more than one language, and they become a translator.

Translators are needed in Indonesia because of the limitation of Indonesian people who are mastering a foreign language. The ability in writing textbooks in Bahasa 
Indonesia is limited. The other reason because there are some attempts to take science and technology from other countries to Indonesia. Moreover, the translators regarded as the most effective and efficient way to take it. To be a translator is not easy because become a translator, you have to complete the requirements, such as; mastering two languages, having communicative competence, and having transfer competence.

Translation is transferring ideas from one language to another language without changing the meaning. It is like what Catford (1974) said that "translation is the replacement of textual material in one language (source language) by equivalent textual material in another language (target language)". And then Nida and Taber (1974) said that "translation is the reproducing in the receptor language closest natural equivalent of the source language message, first in terms of meaning and secondly in terms of style". Moreover, the last is the definition from Brislin (1976), Brislin said that "Translation is a general term referring to the transfer of thoughts and ideas from one language (source) to another (target) whether the language is in written or oral form, whether the language has established orthographies or do not have standardization, or whether one or both is based on sign, as with sign language of the deaf." Translation is not only for books, speech, film but advertisement also needs translation.

Advertisement is a notice or announcement in a public medium promoting a product, service, or event or publicizing a job vacancy. We can see advertisement wherever and whenever we are. The more we see an advertisement, the more we know that product and then we curious about it and want to have the product. We can find the advertisement in the street, $\mathrm{tv}$, radio, internet, even in a magazine.

Garuda Indonesia is the flag-carrier of Indonesia, the largest archipelago national. Garuda Indonesia flew to over 40 domestic and 36 international destinations and was named as World's Best Regional Airline by Skytrax. Flew for the first time in 1949, today Garuda Indonesia carries more than 25 million passengers annually. However, as the best airline in Indonesia, Garuda Indonesia should give its best services to passengers through domestics and foreigners. One of its services is to provide bilingual magazine to the passengers. As explained above that Garuda Indonesia carries more than 25 million passengers annually, I wonder if the bilingual magazine has terrible quality of translation. The magazine tells essential information such as; cultures, foods, fashion, automotive, hotels, and watches.

Nowadays watch is a thing that everybody should have, no matter the profession is. Because of it, watch advertisement always has space in people's heart, and it always interest people to see the advertisement. Although the advertisement contains short sentences, but there is always a mistake in translating the advertisement from English to Bahasa Indonesia. It triggers the researcher to show the mistake of the watch advertisement's translation considering Garuda Indonesia airline is the best airline in Indonesia, so it is such fatal if it still stands with it. 


\section{Literature Review}

As a consideration, this research about genre-based translation, the researcher has been reviewed some previous research, such as; Diah Kristina (2014) in her research entitled "Raising Awareness on the Advantages of Genre and Modality for Translation Purpose: The Case of Promotional Text Genre". This research aims to show how the perspectives of genre and multimodality contribute significantly to the pre-translation process. Ability to digest the source text and to transfer it into a corresponding target text, therefore, fulfil part of the competencies of a qualified translator. The data that is used for this research are five advertorial texts of Garuda Indonesia. This research has shown a model of looking at promotional texts for translation purposes in which a series of steps needs to be adopted. In this research, the researcher does not analyze using Systemic Functional Linguistics.

Jing Luo (2015) in her research entitled "Genre-based Analysis of American Tourism Brochure". This research aims to discuss how discourse should be structured in the writing process. The data used for this research are 35 tourism brochures collected famous scenic spots in Western America. The result of this study indicates that American tourism brochures apply an eight-move generic model. From the pedagogical perspective, the findings weigh on the teaching of English for Special Purposes (ESP) in tourism brochure writing; each move and strategy with the precise purpose of structuring tourist destination image can make proposals for the improvement on brochure creation. In this research, the researcher just analyze the brochure using ESP, and it does not have any correlation with translation.

The other previous study comes from Li YongQing (2013), in her research entitled "A Genre-based Analysis of Hotel Advertisements in Malaysia". The purpose of the study is to use a genre approach to explain the use of advertising language in Malaysia hotel advertisements in attaining their objectives. The study also examines the way the advertisements were written. The study also looks into other aspects of the texts, such as the communicative purposes and the linguistic features. The data that is used for this research are 20 Malaysia hotel advertisements. The result of this study are; First, Malaysia hotel advertisements serve as a communicative medium to persuade potential customers to buy their products or services, provide information portals for potential customers on hotel information and act as a marketing instrument to promote good images and services of hotels. Second, the Five-Move structure is found to be suitable for investigating the structure of Malaysia hotel advertisements. Only Move 4 "Internal Philosophy and Guidelines" is not significant in the data.

The rhetorical moves of Malaysia hotel advertisements include Identifying Service (Brand Name and Highlighting), Establishing Credentials (Location and Offering Rating/ Awards \& Accolades), Introducing Service \& Facilities (Rooms \& Function rooms \& Facilities and Dining \& Bar) and Providing Contact. The Optional Moves or Steps are Expressing General Greetings and Invitation, Background Description and Internal 
Philosophy \& Guidelines. Third, the most common linguistic features are identified in the samples. They are the pronoun „you" and „your", Adjectives, Binomial and Multinomial Expressions, Nominal, Ellipsis and Imperatives. The findings also indicate that some other non-linguistic features are used in the samples, such as colourful and attractive pictures, logos and explicit promotional sub-headings. In all, the findings of this study enrich the promotional genre colony put forward by Bhatia (1993) and add on to the literature in this field for researchers as well as materials for teaching and learning of practical English writing in the field of ESP. This research is not much different from the Jing Luo's research (2015), and this research also does not correlate with translation.

Eva Tuckyta (2016) in her research entitled "Processes in Bahasa Indonesia Tourism Promotion Texts and Its Equivalence in English: A Systemic Functional Linguistic Study". The research aims to describe the dominant of the processes found in the Bahasa Indonesia tourism promotion texts and to describe the verb used in each type of the processes and its equivalence in English. The data collected are divided into major types of clauses: verbal clauses and nonverbal clauses. The data analyzed are the verbal clauses in Bahasa Indonesia since the verb as the central part of the process than compared to its equivalence in English. The result of the research shows there are four types of processes found in both Bahasa Indonesia tourism promotion texts and its equivalence: material, relational, mental, and existential processes. Although this research is using SFL and comparing between Bahasa Indonesia and English, but this research does not tell the reader the specific differences between Bahasa Indonesia and English.

Pakjira (2017) in his research entitled "A Comparative Genre Analysis of Boutique Hotel Webpages in Thailand and New Zealand" The study has four main objectives: 1) to identify moves and steps of English boutique hotel websites in Thailand and New Zealand, 2) to examine visual images presented on boutique hotel websites in Thailand and New Zealand, 3) to compare and contrast the move structures and visual images of these websites, and 4) to explore contextual factors which influence the variation between move structures and the representation of visual images of these websites. The findings show that the depiction of the visual elements across the two countries generally does not differ. Instead, they seem to reflect a homogeneous genre because they conform to the same practices.

That is to say, the designs of the hotel webpages have their integrity, in which the web designers usually follow. From a genre perspective, these similarities in terms of representation of move structures and visual images between these two cultures are seen as either a recurring situation or reproduction of generic conventions of a particular genre, which is considered as a social action within a discourse community. This research is genre-based analysis, but the genre used ESP, not SFL. Moreover, the languages that are used are Thailand and New Zealand, not Bahasa Indonesia.

Based on the research above, the researcher triggers to analyze watch promotional text in "Colours" Magazine of Garuda Indonesia Airline using genre-based analysis, especially SFL. By using SFL in this research, the researcher can tell more the differences 
between the text in English to Bahasa Indonesia. Moreover, by using SFL, the researcher knows the mistakes in text.

\section{Methods}

\section{Text Analyzing using the Perspective of Genre}

Genre analysis is a branch of discourse analysis that explores the specific use of language (Hyland, 2007). There are three approaches to genre studies, namely: Systemic Functional Linguistics (SFL), the New Rhetoric genre theory (NR), and English for Specific Purposes genre theory (ESP). The systemic functional approach represents the concept of genre developed by functional linguists at the Sydney School of systemic functional linguistics. In contrast, the new rhetoric and ESP approaches represent the concept of genre developed by functional linguists in North America and the United Kingdom (Freedman and Medway, 1994). These approaches differ in terms of the educational contexts, their intellectual roots and the emphasis they put to either context or text (Hyland, 2004).

Genre in SFL is seen as 'a staged, goal-oriented social process' which focuses on the purposeful, interactive, and sequential character of different genres and how a language is systematically linked to a context. Genres are considered as a social process because members of a culture have a shared knowledge about something. It is goal-oriented because genres are constructed to achieve things or get something done, and they are staged because meanings are constructed in steps, and it usually takes more than one step for writers to reach their goals. The steps or stages in the tradition of SFL are instead called moves by theorists of ESP such as Swales (1990).

Most of the systemic genre analysts see genre as the context of a situation or contextual configuration, which they described as field, tenor, and mode. These contextual features influence the patterns of texts in terms of text structures and lexicogrammatical patterns. In the perspective of SFL theorists, language is perceived as a system of choices by which writers can communicate certain functions, namely expressing their experiences of the world (experiential metafunction), interacting with others (interpersonal metafunction), and creating coherent messages (textual metafunction). After that, the approach of this research is SFL to know how accurate the translation in watch promotional text in Colours Magazine of Garuda Indonesia Airline.

\section{Discussion}

This chapter discusses the data about genre-based translation in watch promotional text in Colours Magazine of Garuda Indonesia Airline in this three years, start from 2016-2018. The Magazine that is used as data is January Edition in each year. The Differences from the appearance: 
Tefur Nur Rohman: A Genre-Based Translation of Watch Promotional Text in Colours Magazine of Garuda Indonesia Airline

\begin{tabular}{|c|c|c|c|c|c|c|}
\hline & \multicolumn{3}{|c|}{ Source Language } & \multicolumn{3}{|c|}{ Target Language } \\
\hline & 2016 & 2017 & 2018 & 2016 & 2017 & 2018 \\
\hline The Price & $\mathrm{v}$ & - & - & - & - & - \\
\hline Website & $v$ & V & $v$ & - & - & - \\
\hline \multicolumn{7}{|c|}{ The Similar from the appearance: } \\
\hline & \multicolumn{3}{|c|}{ Source Language } & \multicolumn{3}{|c|}{ Target Language } \\
\hline & 2016 & 2017 & 2018 & 2016 & 2017 & 2018 \\
\hline Showing the excellences & $\mathrm{v}$ & $\mathrm{V}$ & $\mathrm{v}$ & $\mathrm{v}$ & $\mathrm{v}$ & $\mathrm{v}$ \\
\hline
\end{tabular}

The analysis using LSF:

Year 2016:

1. BSu:

Black matte dial and black ceramic

insert on the fluted bezel, $\cos C$ certified

Rolex automatic movement

capable of withstanding magnetic

interference, temperature variations

and shocks, black Oysterflex bracelet,

water-resistant to $100 \mathrm{~m}$. US\$25,600

www.rolex.com

\begin{tabular}{|c|c|c|}
\hline $\begin{array}{l}\text { Black matte dial } \\
\text { and } \quad \text { black } \\
\text { ceramic }\end{array}$ & Insert on & the fluted bezel \\
\hline $\begin{array}{l}\text { S } \\
\text { Mood } \\
\text { Theme: } \\
\text { Top Unmarked } \\
\text { Carrier }\end{array}$ & $\begin{array}{l}\text { F/P } \\
\quad \text { Residue } \\
\text { Rheme } \\
\text { Att. Relation P }\end{array}$ & Attribute \\
\hline $\cos C$ & Certified & $\begin{array}{l}\text { Rolex automatic movement [[ capable of Withstanding } \\
\text { magnetic interference, temperature variations and } \\
\text { shocks, black Oysterflex bracelet, water-resistant to } \\
100 \mathrm{~m} .]]\end{array}$ \\
\hline $\begin{array}{l}\text { S } \\
\text { Mood } \\
\text { Theme } \\
\text { Top Unmarked } \\
\text { Attribute }\end{array}$ & $\begin{array}{l}\text { F/P } \\
\quad \text { Residue } \\
\text { Rheme } \\
\text { Att relation pr }\end{array}$ & Carrier \\
\hline
\end{tabular}

US\$25,600: minor

www.rolex.com: minor

BSa: 
Muka jam hitam dengan bahan

keramik pada bezel, mesin COSC certified

Rolex otomatis yang tak

mudah terganggu bahan magnet,

perubahan suhu dan goncangan.

Tali Oysterflex warna hitam, kedap

air hingga $100 \mathrm{~m}$.

\begin{tabular}{|c|c|c|}
\hline \multicolumn{2}{|c|}{$\begin{array}{l}\text { Muka jam hitam [[dengan bahan } \\
\text { keramik pada bezel]] }\end{array}$} & \multirow[t]{2}{*}{ minor } \\
\hline$S$ & & \\
\hline Mesin COSC & bersertifikat & $\begin{array}{l}\text { Rolex otomatis [[yang tak mudah terganggu bahan } \\
\text { magnet, perubahan suhu dan goncangan]] }\end{array}$ \\
\hline $\begin{array}{l}\text { S } \\
\text { Mood } \\
\text { Tema Topikal } \\
\text { Tak Bermarkah }\end{array}$ & $\begin{array}{l}\text { Pol / P } \\
\text { Residu } \\
\text { Rema }\end{array}$ & Pel \\
\hline Pembawa & Proses Relasional & Atribut \\
\hline
\end{tabular}

Tali Oysterflex Warna hitam kedap minor air hingga 100m

From the data above, it can be seen that there are three processes in the source language, but in the target language, there is only a process. Moreover, the process is the same using attributive relational process.

Year 2017:

2. BSu:

Four layered dials in sun-brushed

black and brushed-copper coating make the new Organic Time 7 by Dietrich stand out. There is classic Tritec $\mathrm{C}_{5}$ Super-Luminova on the hands, while the crown is sealed with a double O-ring. Miyota 82-S-7 keeps the watch alive. www.dietrich.luxury 


\begin{tabular}{|c|c|c|c|}
\hline $\begin{array}{l}\text { Four layered } \\
\text { dials in sun- } \\
\text { brushed black } \\
\text { and brushed- } \\
\text { copper coating }\end{array}$ & Make & $\begin{array}{l}\text { The new } \\
\text { Organic Time } 7 \\
\text { [[ by Dietrich ]] }\end{array}$ & Stand out \\
\hline $\begin{array}{l}\text { S } \\
\text { Mood } \\
\text { Theme } \\
\text { Top Unmarked }\end{array}$ & $\begin{array}{l}\text { F/P } \\
\quad \text { Residue } \\
\text { Rheme }\end{array}$ & $C$ & $C$ \\
\hline Carrier & Att Relation $\mathrm{Pr}$ & Attribute & \\
\hline
\end{tabular}

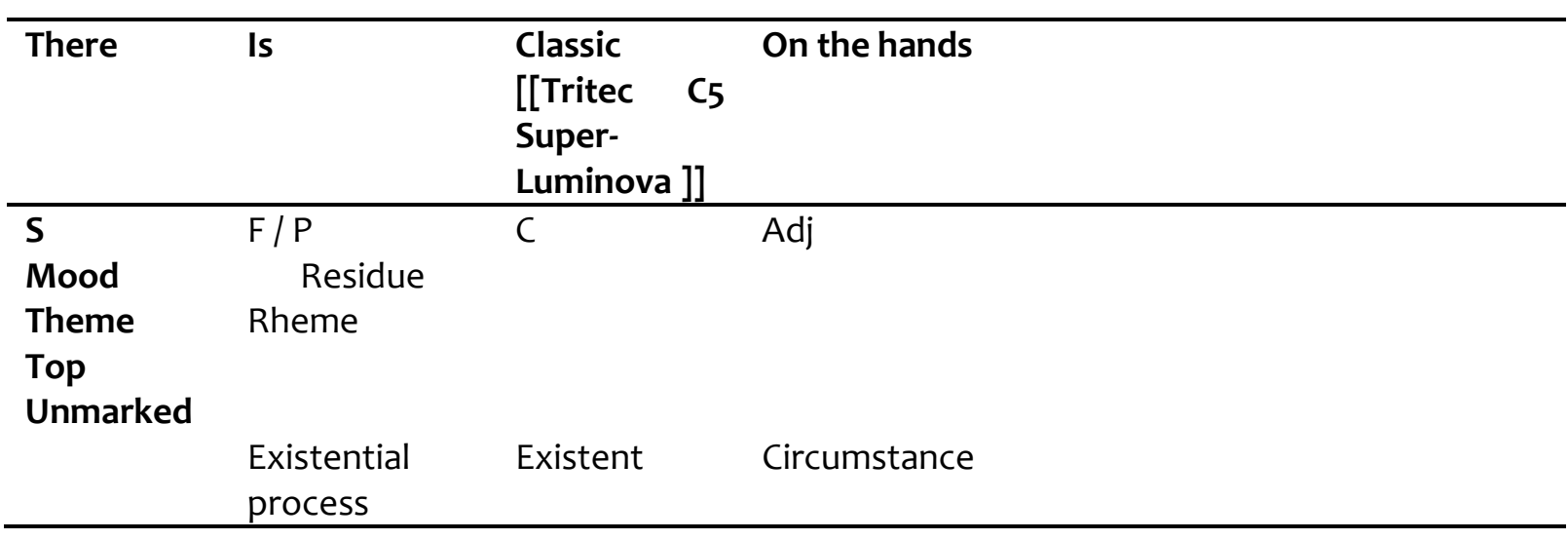

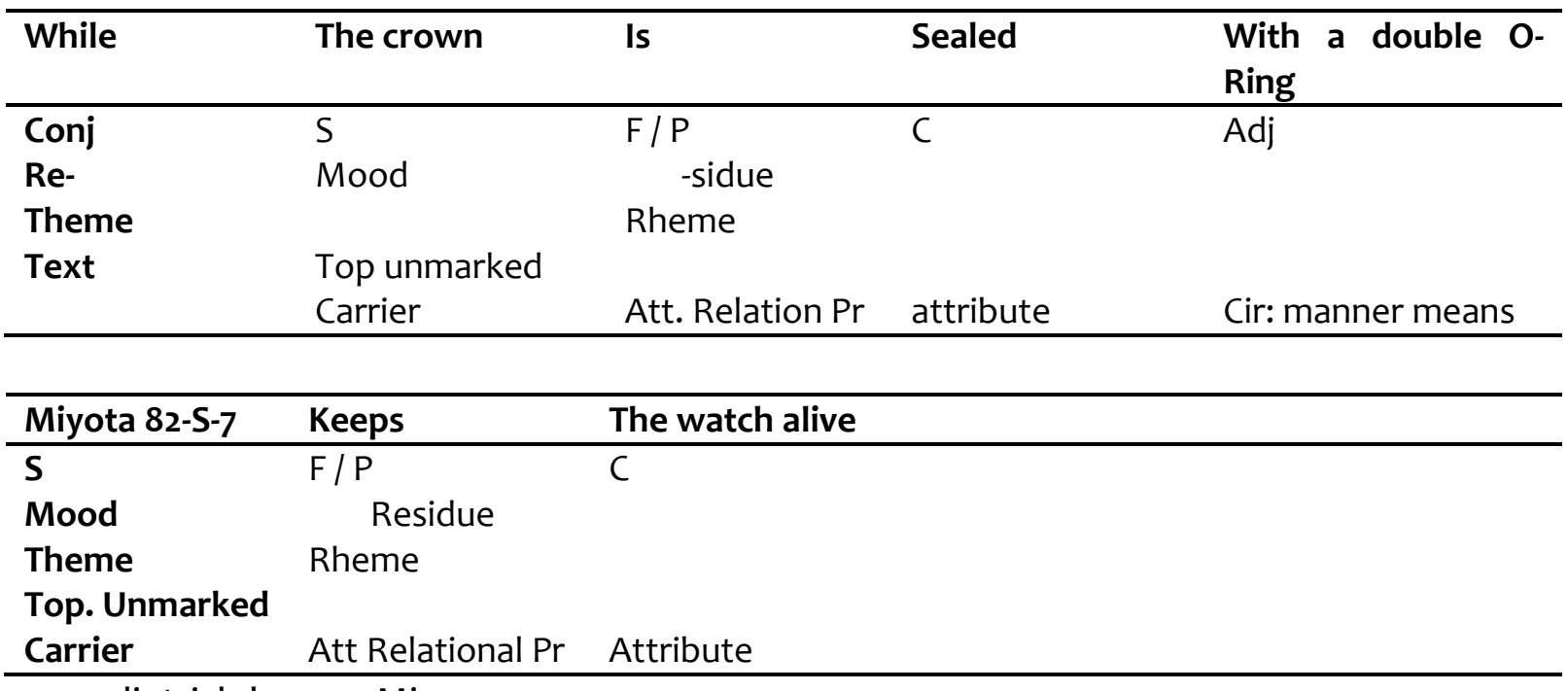

www.dietrich.luxury: Minor

BSa:

Muka jam empat lapis dengan coating

berupa brushed copper dan warna hitam

sun brushed menjadikan arloji ini tampil

beda. Jarum jam dari bahan Classic Tritec

C5 Superluminova, sementara tombol

pemutar dilengkapi dengan o-ring ganda.

Miyota 82-S-7 menjadikan arloji ini 
begitu mengesankan.

\begin{tabular}{llll}
\hline $\begin{array}{l}\text { Muka jam } \\
\text { empat lapis } \\
\text { dengan coating } \\
\text { berupa brushed } \\
\text { copper dan } \\
\text { warna hitam } \\
\text { sun brushed }\end{array}$ & & arloji ini & tampil beda \\
\hline S & Pol / P & Pelengkap & \\
$\begin{array}{l}\text { Mood } \\
\text { Tema: }\end{array}$ & Residu & & \\
$\begin{array}{l}\text { Topikal Tak } \\
\text { Bermarkah }\end{array}$ & & & \\
Pembawa & Proses Relasional & Atribut & Sirkumstan tujuan \\
\hline
\end{tabular}

Jarum jam [[dari bahan Classic Tritec

C5 Superluminova]]

$\mathrm{S}$

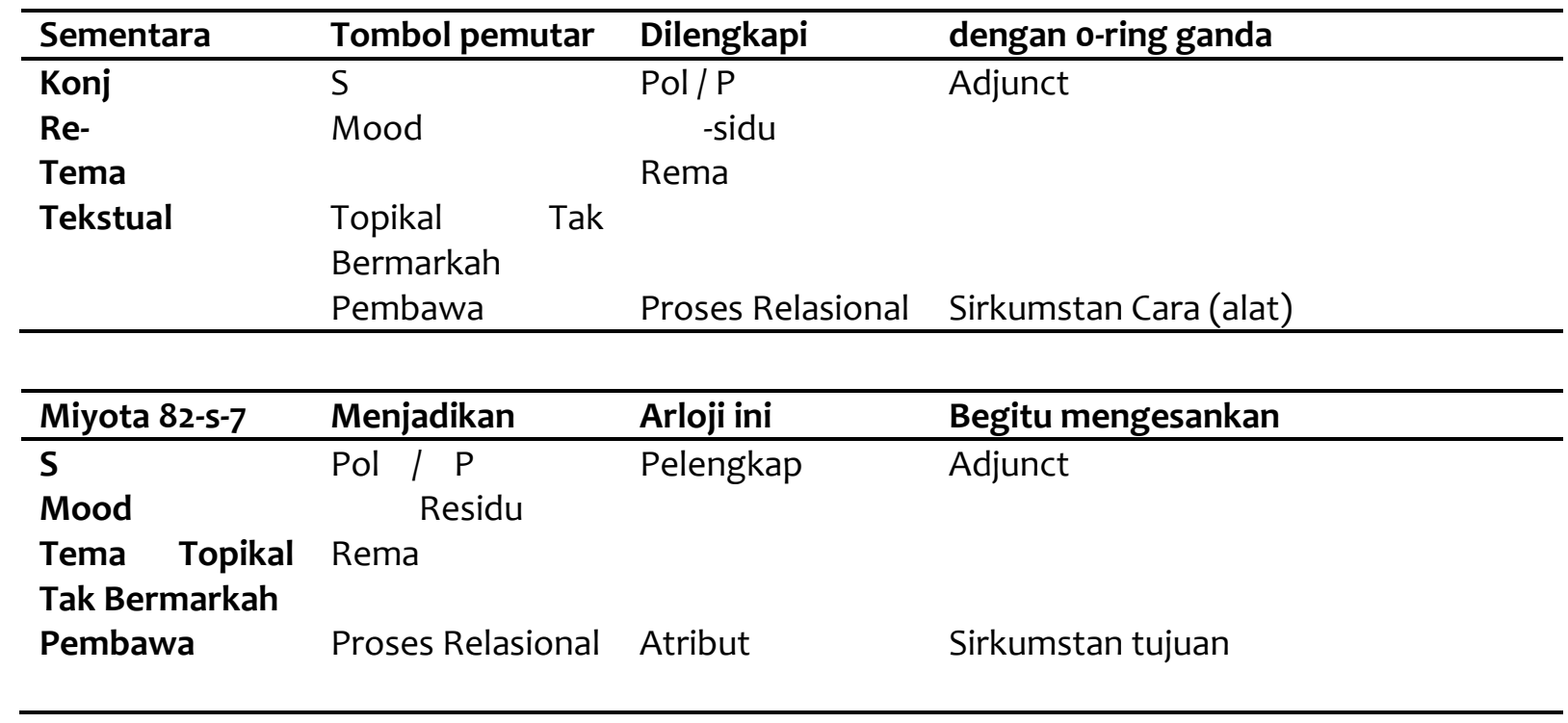

From the data above, it can be seen that in source language has four processes but in the target language has three processes. There is an existential process in a source language, but it could not find in the target language.

Year 2018:

3. BSu:

The new Overseas dual-time model, equipped with an in-house movement, enables simultaneous reading of two time zones are employing coaxial hands. This easily 
adjustable dual-time calibre is housed

in a $41 \mathrm{~mm}$-diameter stainless steel

case water-resistant to $150 \mathrm{~m}$.

www.vacheron-constantin.com

\begin{tabular}{|c|c|c|c|}
\hline $\begin{array}{l}\text { The new } \\
\text { overseas dual- } \\
\text { time model [[ } \\
\text { equipped with } \\
\text { an in-house } \\
\text { movement]] }\end{array}$ & enables & $\begin{array}{l}\text { Simultaneous } \\
\text { reading of two } \\
\text { times zones }\end{array}$ & Using coaxial hands \\
\hline $\begin{array}{l}\text { S } \\
\text { Mood } \\
\text { Theme } \\
\text { Top Unmarked }\end{array}$ & $\begin{array}{l}\text { F / P } \\
\quad \text { Residue } \\
\text { Rheme }\end{array}$ & $\mathrm{C}$ & Adj \\
\hline Carrier & Att Relational Pr & Attribute & Cir. Manner means \\
\hline
\end{tabular}

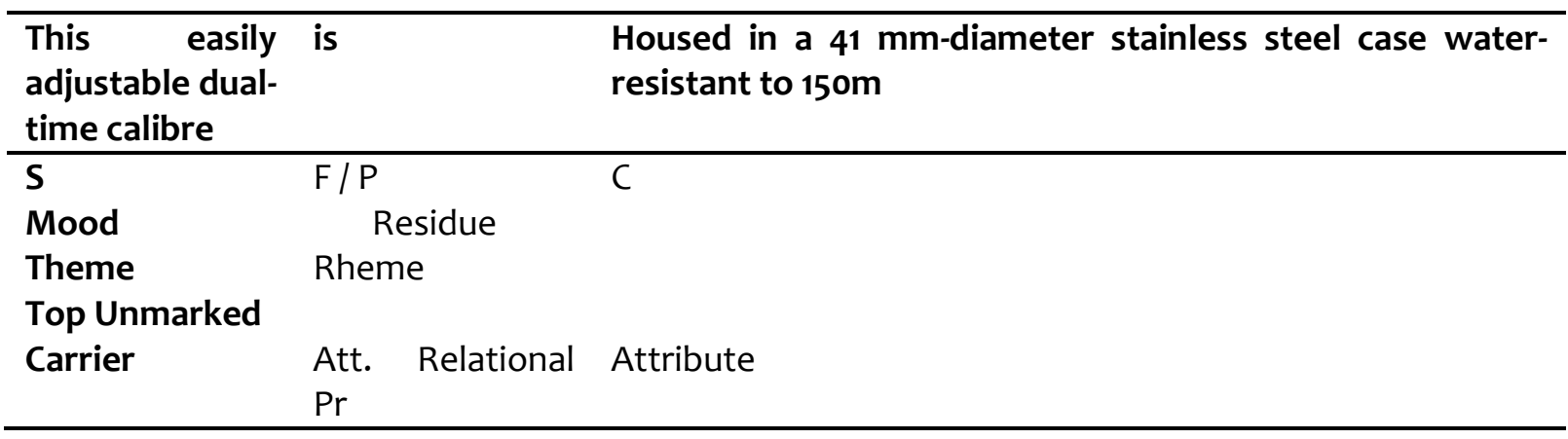

www.vacheron-constantin.com : minor

BSa:

Jam tangan Overseas yang memiliki

model dual time dan dilengkapi in-house

movement ini memungkinkan pemakainya

untuk melihat dua waktu berbeda secara

bersamaan berkat jarum jam koaksial-nya.

Calibre dua waktunya yang bisa disesuaikan

memiliki bingkai stainless steel berdiameter

$41 \mathrm{~mm}$ dan tahan air sampai dengan kedalaman 150 meter.

\begin{tabular}{llll}
\hline Jam tangan memungkinkan & $\begin{array}{l}\text { Pemakainya } \\
\text { untuk melihat } \\
\text { Overseas }\end{array}$ & Berkat jarum jam koaksial-nya. \\
[[yang & & $\begin{array}{l}\text { dua } \begin{array}{l}\text { waktu } \\
\text { berbeda secara } \\
\text { memiliki model }\end{array} \\
\text { bersamaan }\end{array}$ \\
$\begin{array}{l}\text { dual-time dan } \\
\text { dilengkapi in- } \\
\text { house } \\
\text { movement]] ini }\end{array}$ & & & \\
\hline S & Pol / P & Pel & Adj \\
Mood & Residu & & \\
\hline
\end{tabular}




\begin{tabular}{|c|c|c|}
\hline $\begin{array}{l}\text { Tema Topikal } \\
\text { Tak Bermarkah } \\
\text { Pembawa }\end{array}$ & Proses relasional & Sir.sebab: alasan \\
\hline $\begin{array}{l}\text { Calibre dua } \\
\text { waktunya } \\
\text { [[yang bisa } \\
\text { disesuaikan]] }\end{array}$ & Memiliki & $\begin{array}{l}\text { Bingkai stainless steel [[berdiamter } 41 \mathrm{~mm} \text { dan tahan air } \\
\text { sampai dengan kedalaman } 150 \text { meter. }\end{array}$ \\
\hline $\begin{array}{l}\text { S } \\
\text { Mood } \\
\text { Tema Topikal } \\
\text { Tak Bermarkah }\end{array}$ & $\begin{array}{l}\text { Pol / P } \\
\text { Residu } \\
\text { Rema }\end{array}$ & Pel \\
\hline Pembawa & $\begin{array}{l}\text { Proses } \\
\text { Relasional }\end{array}$ & Atribut \\
\hline
\end{tabular}

From the data above, it can be seen that nothing changes between the target language and source language. The differences is only one, in source language has one minor, but the target language does not have.

\section{Conclusion}

This chapter explains about the conclusion and the implication from the research.

1. The Conclusion

This magazine is getting better year by year based on the appearance and SFL. Furthermore, the quality of translation is good, and it can be seen from the translation. There are no much changes between the target language and source language.

2. The Implication

The implication just does not too much-using foreignisation. Most people read the text in the target language because of they do not know the meaning. If it is keep using source language in the target language, it will not help people.

\section{References}

Banks, D. (2019). A systemic functional grammar of English: a simple introduction. Routledge.

Brislin, R. W. (1976). Comparative research methodology: Cross-cultural studies. International journal of psychology, 11(3), 215-229.

Catford, J. C. (1965). A linguistic theory of translation: An essay in applied linguistics. Oxford University Press.

Dewi, E. W., Drajati, N. A., \& Yunus, M. M. (2019). Exploring Intonations in Sesame Street's Puppet Shows: A Phonological Perspective. Issues in Language Studies, 8(2), 32-47.

Dewi, E. W., Nurkamto, J., \& Drajati, N. A. (2019). Exploring Peer-Assessment Practice in Graduate Students'academic Writing. LLT Journal: A Journal on Language and Language Teaching, 22(1), 58-65.

Ding, J. (2018). Theoretical Framework: Collocation in Systemic Functional Perspectives. In Linguistic Prefabrication (pp. 35-54). Springer, Singapore. 
Freedman, A., \& Medway, P. (2003). Genre in the new rhetoric. Routledge.

Habibi, H. (2018). Protecting National Identity Based On The Value Of Nation Local Wisdom. International Journal of Malay-Nusantara Studies, 1(2), 24-40.

Habibi, H. (2016). Peran Ki Dalang Basari (1950-2003) dalam Perkembangan Islam di Gegesik Cirebon. Jurnal Tamaddun: Jurnal Sejarah dan Kebudayaan Islam, 1(2).

Hanan, D. (2017). Cultural specificity in Indonesian film: Diversity in unity. Springer.

Ho, N. K. M. (2019). Evaluation in English and Chinese Marketing Communications: An Adaptation of the Appraisal Framework for the Genre of Luxury Fashion Promotional Texts (Doctoral dissertation, Heriot-Watt University).

Hyland, K. (2004). Genre and second language writing. University of Michigan Press.

Hyland, K. (2007). Genre pedagogy: Language, literacy and L2 writing instruction. Journal of second language writing, 16(3), 148-164.

Hyon, S. (2017). Introducing genre and English for specific purposes. Routledge.

Macken-Horarik, M., Love, K., Sandiford, C., \& Unsworth, L. (2017). Functional grammatics: Reconceptualizing knowledge about language and image for school English. Routledge.

Mingsakoon, P., \& Srinon, U. (2018). Development of secondary school students' generic structure execution in personal experience recount writing texts through SFL genre-based approach. Advances in Language and Literary Studies, 9(6), 112-119.

Nida, E. A., \& Taber, C. R. (Eds.). (1982). The theory and practice of translation (Vol. 8). Brill Archive..

Rohman, T. N., Nababan, M., \& Santosa, R. (2019). An Analysis of Translation in Translated Drama Script Entitled Waiting for Godot. International Journal of Multicultural and Multireligious Understanding, 6(6), 195-200.

Sit, H. H. W., \& Guo, S. (2019). An Exploration of Design Principles to Enhance Students' L2 Acquisition in a Flipped Class. In Digital humanities and new ways of teaching (pp. 111-131). Springer, Singapore.

Swales, J. (1990). Genre analysis: English in academic and research settings. Cambridge University Press.

Watson, L. A., Unsworth, L., \& Chan, E. (2019). Viewer Engagement in Children's Animated Television Shows: A Systemic Functional Perspective.

Yong, L. Y., \& Mei, C. C. Y. (2018). A Genre and Multimodal Analysis of Milk Formula Advertisements in a Local Parenting Magazine. LSP International Journal, 5(2).

https://www.garuda-indonesia.com/id/en/corporate-partners/corporate_index.page accessed on May 28, 2018

https://digilib.uns.ac.id/dokumen/download/264471/MjYoNDcx. Accessed on May, 282018

https://file.scirp.org/pdf/JSS_2015091714291615.pdf. Accessed on May, 282018

http://studentsrepo.um.edu.my/5699/1/TGC100014_LI_YONGQING_(ML).pdf. Accessed on May, 282018

http://www.ccsenet.org/journal/index.php/ijel/article/view/60632 Accessed on May, 282018

http://researcharchive.vuw.ac.nz/handle/10063/6661 Accessed on May, 282018

http://colours-indonesia.com/en/ Accessed on May, 252018

Cite: Rohman, T. N. (2020). A Genre-Based Translation of Watch Promotional Text in Colours Magazine of Garuda Indonesia Airline. Diadikasia Journal, 1(1), 50-61. https://doi.org/10.21428/8c841009.5635b6a9 